\title{
Study on the Principle of College Education Valuation System Reform and Construction
}

\author{
Lili Liu ${ }^{1, a^{*}}$ and Xuehong Chang ${ }^{1, b}$ \\ ${ }^{1}$ Jilin Agricultural University, Changchun, 130118, China \\ aliulili777@163.com, b66414623@qq.com
}

Keywords: Colleges education; Quality; Evaluation system; Construction principles

\begin{abstract}
Education is an important topic at present, which cannot only facilitate the development of various industries but also demonstrates the comprehensive national strength. However, there are a series of problems, which restricts the development as well as the function of education. Therefore, the government currently is vigorously developing education, trying unremitting efforts to carry out reform on education and improve the development of education filed. This paper analyzes one of the factors which will affect the education quality-education evaluation system and illustrates its reform and construction principles.
\end{abstract}

\section{Introduction}

Education is the fundamental to invigorate the country and the evaluation on both education and education quality should be carried out from multiple perspectives. Along with the focus on education, people are paying more attention to education quality. For colleges, education quality can demonstrate the quality of schools and can make it popular so as to attract more students. However, concerning the evaluation ways for education quality, they are lagging behind and improper. In 21st century, talents are important strategic resources and evaluation ways on talents cannot rely on limited criteria, which will drag the development of the nation. In order to change this situation, we have to improve the education quality, which should be clearly regulated in educational outline and the education evaluation means should be focus among the education field. What's more, colleges have to take into consideration multiple evaluation perspectives to carry out fair and excellent results.

\section{The Meaning of Education Quality Evaluation}

Starting from the current education system, education quality evaluation is actually examination, which has its limitations. It can only help to know how students master this subject but cannot know how students' abilities are. A good education quality evaluation means should evaluate students' abilities, which will be of pivotal importance for improving education quality.

The significance of education quality evaluation is to firstly evaluate the learning effect, which can help teachers understand more about students. Based on this, teachers can analyze how students understand the knowledge and they will adjust the teaching schedule. What's more, by analyzing the mistakes shown in the education quality evaluation, teachers can know what kind of knowledge students find it difficult to understand so they can put more emphasis on it; teachers can also understand students' ability development. Moreover, the problems shown in the education quality evaluation are also problems in learning and teaching, which are bilateral. In current education evaluation, teachers get to know their students based on examination results and class performance and students evaluate teachers based on what they behave in class, or they may come up with suggestions, hoping they can correct. Furthermore, the education evaluation quality can help to innovate education. For example, in college class teaching, a lot of students desert, which is not only because of the spoon-feeding education, but also teacher's attitude toward teaching. They have to learn from the education quality evaluation and improve the education quality. 


\section{Current Condition of College Education Evaluation in China}

For most colleges in China, the education quality evaluation is built in class. For teachers, the evaluation way is to randomly visit a class to give teachers result based on comprehensive factors. Even though, colleges nowadays adopt information technology to evaluate teachers, these cases are still rare. What's more, this kind of evaluation means has limitations because it was determined by the supervisor in one class, which cannot demonstrate how teaches pay attention to the follow-ups and education effects and teachers' practical application knowledge still remains to be checked. While carrying out evaluations on students, colleges pay more attention to knowledge transmission and understanding, ignoring abilities cultivation and research, such as independent thinking ability, innovation consciousness, and colleges rarely pay attention to ideology and morality. In addition, education evaluation quality inevitably ignited some disharmonious phenomena.

\section{Principle of College Education Valuation System Reform and Construction}

Humanistic Principle. Humanistic principles take humanistic ideas as the core and mainly pay attention to morality, which cannot separate from the current condition of college education quality. In the market economy era, the result of college education is to help students acquire money and fame and relative education pays more attention to practical knowledge and skills. However, most of colleges forget the fundamental of colleges is education of conducting oneself, which refers to the education in terms of morality, quality and humanity for both teachers and students. Nowadays, reasonable humanistic spirit can encourage them while pure position and money cannot have big effect. For students, knowledge is important but we cannot forget to educate students how to conduct themselves or they cannot be called talents.

Diversification Principle. Diversification principle does not mean one aspect which includes many aspects, such as evaluation indicator, evaluation means and evaluation subjects. Concerning the education quality evaluation, the above evaluation is too general and it is not fair that supervisor randomly picks one class and evaluate on it. So we have to carry out reform on the original education quality evaluation. Diversified education evaluation still focuses on class teaching because only class teaching can demonstrate the ability of teachers. Besides this, we can add other elements such as students' evaluation, suggestions, impression of supervisor and teacher organization etc. and this kind of all-round education quality evaluation will better show the class effect. We can also carry out reform on students' evaluation on education to study their performance, students' impression and self-assessment besides examination results. What's more, we have to explore their practical ability and innovative consciousness so as to be responsible for parents and enterprises.

Just Fair and Open Principle. These three principles are necessary while constructing education evaluation system, which will make the evaluation more convincible. At present, the education quality evaluation system has a lot of problems and some evaluation only focuses on result and ignores the process so people will doubt the authenticity. According to the just, fair and open principle, we have to firstly clear the evaluation standard, procedure. For example, we can add procedures such as test, score and input, which should be implemented, based on strict standards and in a just, fair and open environment; secondly, the evaluation channel should be open and the education quality evaluation is a comprehensive process with all organizations participating in. In addition, there should be platforms to deal with the evaluations so that everyone can express opinions. Furthermore, the evaluation process, result and information should also adhere to the above principle so as to ensure the authority and transparency so that it will be easier for people to accept the evaluation result.

Science-based Principle. So called science-based principle means that colleges education quality evaluation should be carried out on both teachers and students, which should adapt to the development and reform rules of colleges. It cannot adopt the traditional evaluation assessment which lags behind and cannot carry out too quickly. Concerning the evaluation index and structure, we have to understand the existence of education subjects and the evaluation process as well as 
result should demonstrate the specialties, paying same attention to the position of teachers and students.

\section{Conclusion}

In the premise that the government is paring soaring attention to education, we now analyze the education quality evaluation system and elaborate its meaning and problems. Based on this, we come up with reform and construction principles and systemically analyze the rules that colleges have to obey to make contributions to education filed. However, the education quality system condition now is not optimistic, which needs mutual efforts of all faculties so as to start a new chapter.

\section{References}

[1] Xiaohuan Zheng. Local governments to promote energy conservation and emissions reduction counter measures research [D]. 2014 Tianjin University of commerce (In Chinese).

[2] Yanhong Xiao. Explore on the college education quality evaluation system [J].Education anVocation, 2015.36: 47-49. (In Chinese)

[3] Zhiguo Sun, Hai-ping Xu. The teaching reform discussion situation of energy saving and emission reduction in environmental systems [J]. Journal of education teaching exploration (9): 2012-60. (In Chinese).

[4] Ya-bin Xu. Research and practice of University-enterprise cooperation personnel training mode [J].Computer education .2013 (2): 1-4. (In Chinese).

[5] $\mathrm{Wu} \mathrm{Yu}$. Explore on the Principle of College Education Valuation System Reform and Construction [J].Trade and Practices, 2015.14: 242. (In Chinese)

[6] Yangx Li, Yuhui Su. Principle of College Education Valuation System Reform and Construction [J]. Heilongjiang Education (Theory and Practice 2015.06:76-77. (In Chinese)

[7] Yunlin Zhao. Local undergraduate course of teaching reform breakthrough [J]. Practice teaching 2008 (12): 51-52. (In Chinese). 